\title{
EVALUASI PROGRAM MANAJEMEN PEMBELAJARAN PADA SEKOLAH ADIWIYATA KALIMANTAN TIMUR
}

\author{
Muhammad Eka Mahmud \\ IAIN Samarinda, Kalimantan Timur, Indonesia \\ Email :eka.mahmud@yahoo.com \\ Suratman \\ IAIN Samarinda, Kalimantan Timur, Indonesia \\ Email:suratman@yahoo.com
}

DOI: http:/ / doi.org/10.33650/al-tanzim.v3i2.691

\begin{tabular}{l|l|l} 
Received: September 2019 & Revised: November 2019 & Approved: Desember 2019 \\
\hline
\end{tabular}

\begin{abstract}
:
This study aims to analyze the evaluation of learning management programs in the field of Islamic education, so that the quality of learning in adiwiyata schools is truly in accordance with the wishes of the community at large. This research uses a qualitative approach with case study. The research site is at Sekolah Menengah Umum Negeri 8 Samarinda dan Sekolah Menengah Umum Negeri 1 Tenggarong, East Kalimantan. The results showed that The results showed that Islamic education learning management is done through planning, implementation, evaluation by integrating the principles of adiwiyata schools in learning, by implementing the principal's policy strategy through continuous planning, implementation, mentoring and evaluation. The achievement of the evaluation results of the management of Islamic religious education learning in the context of integrated learning is very significant, with a value of 7.75 (good), development of learning tools 7.59 (good), monolithic learning 7.19 (good), and through extracurricular activities 6, 90 (good). The impact of management learning in Islamic education is; (a) the establishment of cooperation between schools and related parties in environmental management, (b) creative and innovative teaching staff, and (c) familiar with the attitude of environmental love and the use of used materials.
\end{abstract}

Key words : Evaluation, learning management, adiwiyata

\begin{abstract}
Abstrak
Penelitian ini bertujuan untuk menganalisis tentang evaluasi program manajemen pembelajaran pada bidang studi Pendidikan Agama Islam, sehingga diharapkan mutu pembelajaran pada sekolah adiwiyata benar-benar sesuai dengan keiginan masyarakat secara luas. Penelitian ini menggunakan pendekatan kualitatif jenis studi kasus, dengan situs penelitian di Sekolah Menengah Umum Negeri 8 Samarinda dan Sekolah Menengah Umum Negeri 1 Tenggarong Kalimantan Timur. Hasil penelitian menunjukkan bahwa manajemen pembelajaran Pendidikan Agama Islam dilakukan melalui perencanaan, pelaksanaan, evaluasi dengan mengintegrasikan prinsip sekolah adiwiyata dalam pembelajaran, dengan menerapkan strategi kebijakan kepala sekolah melalui penyusunan rencana, pelaksanaan, pendampingan dan evaluasi secara berkesinambungan. Ketercapaian hasil evaluasi program manajemen pembelajaran Pendidikan Agama Islam dalam konteks pembelajaran terintegrasi sangat signifikan, dengan nilai 7,75 (baik), pengembangan perangkat pembelajaran 7,59 (baik), pembelajaran secara monolitik 7,19 (baik), dan melalui kegiatan ekstrakurikuler 6,90 (baik). Dampak manajemen pembelajaran Pendidikan Agama Islam adalah; (a) terjalinnya kerjasama pihak sekolah dengan pihak terkait dalam pengelolaan lingkungan, (b) tenaga pendidik kreatif dan inovatif, dan (c) terbiasa dengan sikap cinta lingkungan danpemanfaatan bahan bekas.
\end{abstract}

Kata Kunci : Evaluasi, manajemen Pembelajaran, adiwiyata 


\section{PENDAHULUAN}

Dewasa ini, pembangun di Indonesia mengalami perkembangan yang cukup pesat pada berbagai sector (Wibowo, 2018). Pembangunan berkelanjutan telah menjadi komitmen dan tanggung jawab bersama untuk menyelamatkan bumi dari kerusakan dan kehancuran, akibat pembangunan yang tidak memperhatikan kelestarian lingkungan. Pembangunan berkelanjutan berusaha untuk memahami interaksi antara alam dan masyarakat dalam rangka untuk mempromosikan transisi menuju keberlanjutan. Inti dari pembangunan berkelanjutan adalah memenuhi kebutuhan dasar manusia sambil menjaga sistem pendukung kehidupan planet bumi (Hallfreosdóttir, 2011).

Pesatnya pembangunan tersebut tentunya menimbulkan dampak negatif pada lingkungan, diantaranya adalah kerusakan dan pencemaran lingkungan hidup yang mengakibatkan penurunan kualitas atau degradasi lingkungan (Maryani, 2014).

Adanya permasalahan lingkungan tersebut disebabkan oleh adanya peningkatan populasi atau pertambahan penduduk yang sangat tinggi, sehingga menimbulkan dampak yang cukup besar terhadap keseimbangan ekosistem, di mana tekanan lingkungan hidup juga menjadi besar akibat perbuatan manusia terhadap alam (Tompodung, Rushayati, \& Aidi, 2018). Kurangnya kepedulian masyarakat terhadap lingkungan hidup, menjadi faktor pendukung atas rusaknya lingkungan hidup, seperti perilaku yang merusak lingkungan, menebang hutan sembarangan, kebiasaan membuang sampah tidak pada tempatnya. Perilaku masyarakat yang demikian menyebabkan dan mendatangkan permasalahan lingkungan, bencana, seperti; kekeringan, kebakaran hutan, tanah longsor, banjir, yang banyak menimbulkan kerugian materi maupun non materi.

Penyelesaian masalah dan krisis lingkungan yang terjadi saat ini dan masa yang akan dating, tidak bisa hanya dilakukan melalui pendekatan teknis, akan tetapi diperlukan puka pendekatan pendidikan moral yang dilakukan secara terencana, sistematis dan massif. Membangun moral yang baik akan menjadi modal utama bagi manusia untuk berperilaku etis dalam mengatur hubungan antara dirinya dengan alam semesta.

Pendidikan Islam merupakan bekal yang kuat untuk dijadikan pondasi dalam membangun manusia Indonesia seutuhnya, bahkan ia diakui sebagai benteng dari pengembangan IPTEK dan IMTAQ, sehingga kehadiran pendidikan Islam diyakini sebagai modal untuk menggapai kebahagiaan dunia akhirat. Oleh karena itu, pembelajaran agama di berbagai sekolah perlu dikelola dengan baik, sehingga diharapkan dapat membentuk kesalehan pribadi dan sekaligus kesalehan sosial dan tidak melahirkan sikap fanatisme; menumbuhkan sikap intoleran dikalangan peserta didik dan masyarakat Indonesia; memperlemah kerukunan hidup beragama (Muhaimin, 2003). 
Al-Tanzim : Jurnal Manajemen Pendidikan Islam E-ISSN: 2549-5720 P-ISSN: 2549-3663

Vol. 03 No. 02 (2019) : 85-96

https:// ejournal.unuja.ac.id/index.php/al-tanzim

Mencermati kondisi pendidikan Islam dewasa ini, harus mampu mengedepankan pembentukan moral (moral force) terlebih di sekolah umum, yang dipersepsikan pembelajaran agama dianggap kurang efektif, karena hanya diberi alokasi waktu hanya dua jam dalam seminggu, ditambah dengan kelemahan pembelajaran Pendidikan Agama di lapangan, yaitu; (1) pendekatan masih cenderung normative-tekstual dan seringkali tanpa dibarengi ilustrasi konteks sosial budaya, (2) kurikulum yang dirancang baru menawarkan minimum informasi bagi peserta didik, (3) guru kurang menggali metode yang mungkin dapat dipakai untuk Pendidikan Agama, sehingga pelaksanaan terkesan monoton, (4) keterbatasan sarana prasarana sehingga pengelolaan Pendidikan Agama cenderung seadanya.

Di samping itu, beberapa kekurangan dan kelemahan dalam mengoptimalkan proses belajar mengajar Pendidikan Agama Islam di sekolah, karena itu secara praktis beberapa sekolah yang mendapat predikat Adiwiyata telah melaksanakan manajemen pembelajaran Pendidikan Agama Islam di Kalimantan Timur ini yang sudah mengatasi persoalan-persoalan tersebut. Pentingnya pendidikan lingkungan melalui program adiwiyata, disebabkan karena kondisi lingkungan sudah semakin memprihatinkan. Hal ini dipicu oleh ulah manusia yang mengeksploitasi sumberdaya alam dan lingkungan tanpa batas. Berkaitan dengan perilaku manusia terhadap kondisi sumberdaya alam dan lingkungan yang cenderung tidak peduli, maka mengubah perilaku menjadi prioritas utama dalam mengatasi krisis lingkungan (Maryani, 2014).

Banyak penelitian tentang adiwiyata yang dilakukan oleh para peneliti, diantaranya; Maryani (2014) menyatakan bahwa evaluasi pelaksanan program adiwiyata di SDN Ungaran I Yogyakarta berjalan dengan baik, yaitu dengan pencapaian kriteria yang sangat tinggi pada aspek input, konteks dan proses. Iswari \& Utomo (2017) melalui hasi penelitiannya menjelaskan bahwa peserta didik yang belajar di sekolah yang menerapkan konsep adiwiyata memiliki tingkat pemahaman, sikap dan tindakan terhadap lingkungan lebih baik bila dibandingkan dengan sekolah yang tidak menerapkan program adiwiyata. Begitu juga dengan penelitian (Daryanto, 2013) yang menyatakan bahwa terdapat perbedaan yang sangat signifikan pada aspek pengetahuan, perilaku dan sikap dari para warga sekolah terhadap lingkungannya, bagi sekolah yang menerapkan program adiwiyata dengan sekolah non adiwiyata.

Manajemen pembelajaran merupakan serangkaian kegiatan yang dirancang dan dikembangkan untuk mencapai tujuan dalam pembelajaran secara optimal, sebagai upaya untuk mencapai tujuan dimaksud, dapat dilakukan beberapa langkah strategis, yaitu; mengidentifikasi kebutuhan peserta didik, merumuskan tujuan pembelajaran, menganalisis kebutuhan untuk mengtransformasikan tujuan pembelajaran, merancang pembelajaran, melaksanakan kegiatan pembelajaran dan melakukan penilaian pembelajaran, (Hamalik, 2002). 
Berangkat dari penelitian tersebut di atas, peneliti tertarik untuk mengkaji aspek yang belum dikaji oleh peneliti sebelumnya, yaitu tentang evaluasi program manajemen pembelajaran pada bidang studi Pendidikan Agama Islam di Kalimantan Timur, mengingat banyak keberhasilan yang telah dicapai oleh kedua lembaga tersebut dalam melaksanakan program adiwiyata melalui kegiatan pembelajarannya. Keunikan penelitian ini terletak pada fokus peneliti yang secara spesifik membahas dan mengkaji dalam aspek evaluasi program manajemen pembelajaran pada bidang studi Pendidikan Agama Islam di Sekolah Menengah Umum Negeri 8 Samarinda dan Sekolah Menengah Umum Negeri 1 Tenggarong Kalimantan Timur, sehingga menjadi keunikan dan kebaruan dalam penelitian ini.

\section{Evaluasi dalam Program Pembelajaran}

Pada tataran teoritis, evaluasi mengandung beberapa makna, yaitu (evaluation), pengukuran (measurement), penilaian (Assessment). Evaluasi sebagai sebuah proses, menentukan terhadap hasil yang telah dicapai dalam berbagai kegiatan yang telah direncanakan untuk mendukung tercapainya tujuan. Evaluasi merupakan kegiatan mencari sesuatu yang berharga tentang sebuah tujuan dalam pembelajaran, termasuk mencari informasi yang bermanfaat dalam menilai keberadaan suatu program, produksi, prosedur, serta alternatif strategi yang diajukan untuk mencapai tujuan yang sudah ditentukan.

Evaluasi merupakan proses penggambaran, pencarian, dan pemberian informasi yang sangat bermanfaat bagi proses pengambil keputusan dalam menentukan alternatif keputusan. Hal tersebut dapat dipahami bahwa, evaluasi merupakan kegiatan untuk mengumpulkan informasi tentang bekerjanya sesuatu, yang selanjutnya informasi tersebut digunakan untuk menentukan alternatif yang tepat dalam mengambil sebuah keputusan (Suyatno, 2015).

Pada konteks tersebut, program dapat diartikan sebagai sebuah rencana dalam kegiatan pembelajaran, seperti keinginan untuk melanjutkan ke pendidikan yang lebih tinggi, mencari pekerjaan, membantu orang tua dalam membina usaha, atau mungkin juga belum menentukan program apa pun. Selain itu, terdapat juga anak yang sangat tergantung pada oran tua sehingga akan memberi jawaban bahwa program masa depan menunggu keputusan orang tuanya.

Apabila program ini langsung dikaitkan dengan evaluasi program maka program didefinisikan seebagai implementasi dari suatu kebijakan, berlangsung dalam proses bekesinambungan, dan terjadi dalam organisasi. Karena itu terdapat tiga hal penting dan perlu ditekankan dalam menentukan program, yaitu: (1) realisasi atau implementasi suatu kebijakan, (2) terjadi dalam waktu relatif lama-bukan kegiatan tunggal tetapi jamak bekesinambungan, (3) terjadi dalam organisasi yang melibatkan sekelompok orang. 
Al-Tanzim : Jurnal Manajemen Pendidikan Islam E-ISSN: 2549-5720 P-ISSN: 2549-3663

Vol. 03 No. 02 (2019) : 85-96

https:// ejournal.unuja.ac.id/index.php/al-tanzim

Sebuah program bukan hanya kegiatan tunggal yang dapat diselesaikan dalam waktu singkat, tetapi merupakan kegiatan yang berkesinambungan karena melaksanakan suatu kebijakan. Oleh karena itu, sebuah program dapat berlangsung dalam kurun waktu relatif lama. Pengertian program adalah suatu unit atau kesatuan kegiatan makan program merupakan sebuah sistem, yaitu rangkaian kegiatan yang dilakukan bukan hanya satu kali tetapi berkesinambungan. Pelaksanaan program selalu terjadi di dalam organisasi yang artinya harus melibatkan sekelompok orang. Pengertian program yang dikemukakan di atas adalah pengertian secara umum. Karena itu, makna dari evaluasi program itu sendiri mengalami proses pemantapan. Definisi yang terkenal evaluasi program dikemukakan Ralph Tyler, yang mengatakan bahwa evaluasi program adalah proses untuk mengetahui apakah tujuan pendidikan sudah dapat terealisasikan, (Tyler, 1950). Definisi yang lebih diterima masyarakat luas dikemukakan Cronbach, mengemukakan bahwa evaluasi program adalah upaya menyediakan informasi untuk disampaikan kepada pengambil keputusan. Sehubungan dengan definisi tersebut The standford Evaluation Consorsium Group menegaskan bahwa meskipun menyediakan informasi, evaluator bukanlah pengambil keputusan suatu program (Cronbach, 1982).

Demikian evaluasi program adalah suatu proses untuk mengetahui apakah proses sebuah program sudah berjalan dengan ketentuan atau belum, dan penyediaan informasi untuk pengambilan sebuah keputusan. Tujuan dari diadakannya evaluasi program adalah untuk mengetahui pencapaian tujuan program dengan langkah mengetahui keterlaksanaan kegiatan program, karena evaluator program ingin mengetahui bagian mana dari komponen dan subkomponen program yang belum terlaksana dan apa sebabnya. Oleh karna itu, sebelum mulai dengan langkah evaluasi, evaluator perlu memperjelas dirinya dengan apa tujuan program yang akan dievaluasi. Kegiatan evaluasi program sangat berguna bagi pengambilan keputusan dan kebijakan lanjutan program, hasil evaluasi adalah sebuah rekomendasi dari evaluator untuk pengambil keputusan (decision maker). Ada empat kemungkinan kebijakan yang dapat dilakukan berdasarkan hasil dalam pelaksanaan sebuah program keputusan; a) menghentikan program, karena dipandang bahwa program tersebut tidak ada manfaatnya, atau tidak dapat terlaksana sebagaimana diharapkan, b) merevisi program, karena ada bagian-bagian yang kurang sesuai dengan harapan (terdapat kesalahan tetapi hanya sedikit), c) melanjutkan program, karena pelaksanaan program menunjukkan bahwa segala sesuatu sudah berjalan sesuai dengan harapan dan memberikan hasil yang bermanfaat, d) menyebarluaskan program (melaksanakan program di tempat-tempat lain atau mengulangi lagi program di lain waktu), karena program tersebut berhasil dengan balk maka sangat baik jika dilaksanakan lagi di tempat dan waktu yang lain.

Manajemen pembelajaran pada hakikatnya menduduki peranan yang sangat penting dalam mensukseskan kegiatan pembelajaran di kelas. Hal ini 
disebabkan karena manajemen pembelajaran merupakan pengaturan semua kegiatan pembelajaran yang dikategorikan dalam kurikulum inti mapun penunjang.

Management is getting things done trough people. In bringing a bout this coordinating of group activity, the manager, as a manager plans, organizes, staffs, direct, and control the activities other people (Hakim, 2017). Selain lain itu, manajemen dipahami sebagai usaha mencapai suatu tujuan tertentu melalui kegiatan orang lain. Dengan demikian manajer mengadakan koordinasi atas jumlah aktivitas orang lain yang meliputi perencanaan, pengorganisasian, penempatan, pengarahan, dan pengendalian (Syamsuddin, 2017).

Definisi tersebut menunjukkan bahwa manajemen merupakan aktivitas mengelola orang-orang dalam pengambilan keputusan, proses pengorganisasian dan memakai sumber-sumber menyelesaikan tujuan yang sudah ditentukan yang dilakukan oleh seorang pemimpin (Fathorrazi, 2017). Kegiatan seorang pemimpin dalam hal ini adalah mempergunakan cara-cara pemikiran yang ilmiah maupun praktis untuk mencapai tujuan yang sudah ditetapkan dengan melalui kerja sama orang lain sebagai sumber tenaga kerja, serta memanfaatkan sumber-sumber lainnya, dan waktu yang tersedia untuk itu digunakan dengan sebaik-baiknya (Pane \& Darwis Dasopang, 2017).

Sedangkan belajar adalah suatu proses perubahan tingkah laku, perubahan itu mengarah kepada tingkah laku yang lebih baik yang terjadi melalui latihan atau pengalaman. Perubahan tingkah laku karena belajar menyangkut berbagai aspek kepribadian, baik psikis maupun pisik (Amin, Siswanto, \& Hakim, 2018). Pembelajaran mengandung arti setiap kegiatan yang dirancang untuk membantu seseorang mempelajari suatu kemampuan dan atau nilai yang baru.

Pembelajaran merupakan perbuatan yang kompleks. Artinya, kegiatan pembelajaran melibatkan banyak komponen dan faktor yang perlu dipertimbangkan. Untuk itu, perencanaan maupun pelaksanaan kegiatannya membutuhkan pertimbangan-pertimbangan yang arif dan bijak. Seorang guru dituntut untuk bisa menyesuaikan karakteristik siswa, kurikulum yang sedang berlaku, kondisi kultural, fasilitas yang tersedia dengan strategi pembelajaran yang akan disampaikan kepada siswa agar tujuan dapat dicapai. Strategi sangat penting bagi guru karena sangat berkaitan dengan efektivitas dan efisiensi dalam proses pembelajaran (Samrin, 2015).

Manajemen pembelajaran pada hakikatnya merupakan sebuah perpaduan yang terdiri dari berbagai unsur dan saling mempengaruhi, melalui proses perencanaan, pelaksanaan, pengorganisasian dan pengevaluasian untuk membantu kegiatan pembelajaran agar dapat berjalan secara efektif dan efesien (Anggreni, 2016). 
Al-Tanzim : Jurnal Manajemen Pendidikan Islam E-ISSN: 2549-5720 P-ISSN: 2549-3663

Vol. 03 No. 02 (2019) : 85-96

bttps:/ / ejournal.unija.ac.id/ index.php/al-tanzim

\section{Potret Sekolah Adiwiyata dalam Membangun Karakter Peserta Didik}

Pendidikan di sekolah merupakan salah satu bagian dari kegiatan untuk mendidik penerus bangsa, dalam mengedepankan kecerdasan intelektual, mendidik moral, budi pekerti, dan watak atau karakter. Tujuan Pendidikan karakter adalah membangun karakter setiap siswa untuk membangun kepribadian dan perilaku yang bersifat positif melalui lingkungan hidup yang dapat mempengaruhi pengetahuan, keterampilan dan kesejahteraan manusia untuk melakukan aktifitas sosial.

Berbicara mengenai pendidikan, sangat menarik sekali jika membahas mengenai pendidikan lingkungan yang diterapkan pada sekolah melalui program Adiwiyata. Program sekolah Adiwiyata merupakan bentuk komitmen pemerintah terhadap pengelolaan dan perlindungan lingkungan melalui pendidikan guna mendorong terciptanya pengetahuan dan kesadaran warga sekolah dalam pelestarian lingkungan hidup. Kebijakan yang dibuat oleh pemerintah yaitu melalui Peraturan Menteri Lingkungan Hidup Nomor 5 tahun 2013 diterjemahkan menjadi program sekolah Adiwiyata (Syafrudin, 2016).

Program Adiwiyata adalah program yang komprehensif melibatkan semua stakeholders baik di sekolah dan masyarakat untuk membantu meningkatkan kepedulian lingkungan, khususnya para siswa (Pradini, Sudjanto, \& Nurjannah, 2018). Kegiatan tersebut melibatkan semua warga sekolah untuk ikut serta dalam pengelolahan lingkungan. Sebagai tempat belajar, sekolah memiliki peran khusus untuk bermain; sekolah dapat membantu siswa untuk memahami dampak perilaku manusia di bumi ini, dan menjadi tempat di mana hidup yang berkelanjutan (Sungkowo, 2005).

Sekolah Adiwiyata mempunyai pengertian atau makna sebagai tempat yang baik dan ideal di mana dapat diperoleh segala ilmu pengetahuan dan berbagai norma serta etika yang dapat menjadi dasar manusia menuju terciptanya kesejahteraan hidup dan menuju kepada cita-cita pembangunan berkelanjutan. Dalam program ini diharapkan semua warga sekolah ikut terlibat dalam kegiatan sekolah menuju lingkungan yang sehat serta menghindari dampak lingkungan yang negative.

Program ini juga mengembangkan norma dasar, antara lain: Kebersamaan, Keterbukaan, Kesetaraan, Kejujuran, Keadilan, dan Kelestarian Lingkungan Hidup. Sehubungan dengan itu prinsip utama dari program Adiwiyata adalah: (1) Partisipatif, artinya setiap kegiatan harus melibatkan seluruh warga sekolah mulai dari perencanaan, pelaksanaan sampai evaluasi sesuai tugas dan tanggung jawab masing-masing; dan (2) Berkelanjutan, artinya seluruh kegiatan harus dilakukan secara terencana dan terus menerus (Pradini et al., 2018).

Adiwiyata diterapkan dalam dunia pendidikan disebabkan dalam dunia pendidikan lebih mudah mempelajari dan menerapkan segala ilmu pengetahuan dan berbagai norma serta etika untuk mencapai cita-cita 
pembangunan berkelanjutan (Dwi Rahmah, 2014). Program Adiwiyata yang dilaksanakan oleh sekolah memiliki misi mulia, yaitu menciptakan kondisi yang ideal bagi sekolah sebagai tempat pembelajaran dan penyadaran warga sekolah (guru, siswa dan karyawan) sehingga nantinya sekolah tersebut dapat bertanggung jawab dalam upaya penyelamatan lingkungan hidup dan pembangunan yang berkelanjutan. Program Adiwiyata dalam hal ini ditujukan untuk mewujudkan warga sekolah yang bertanggung jawab dalam upaya perlindungan dan pengelolaan lingkungan hidup melalui tata kelola sekolah yang baik untuk mendukung pembangunan berkelanjutan (Iswari \& Utomo, 2017).

Tujuan utama penekanan konsep lingkungan di sekolah adalah untuk menjelaskan fungsi manusia dalam menjaga alam semesta dan menunjukkan cara menjaga kualitas lingkungan alam untuk kepentingan bersama pada masa yang akan datang. Di sinilah para guru yang mengajar siswa, baik di dalam maupun di luar kelas harus memahami betul arti penting konsep lingkungan (Adelia, 2010). Konsep pembelajaran menggunakan lingkungan memberikan peluang yang sangat besar bagi peserta didik, untuk meningkatkan hasil belajarnya (Hamzah, 2012).

Kelancaran kegiatan belajar mengajar serta kelas yang kondusif dapat tercipta juga dengan tanaman dan tumbuh tumbuhan yang dihasilkan melalui peserta didik yang cinta dan peduli terhadap lingkungan sekolah melalui bercocok tanam dan berkebun. Tanaman dan tumbuh-tumbuhan mampu menyediakan oksigen yang dapat menjadikan otak berkembang. Semakin banyak oksigen yang didapat, akan semakin meningkat pula kinerja otak. Jika kinerja otak semakin meningkat, para peserta didik akan mampu mengikuti dan mencerna pelajaran yang diberikan oleh guru dengan baik. Tentunya hal itu dapat menjadikan tujuan kegiatan belajar mengajar tercapai (Wiyani, 2013).

Itulah sebabnya, penting bagi sekolah untuk membuat lingkungan yang sejuk dan nyaman melalui penanaman pepohonan dan tumbuh-tumbuhan agar peserta didik mendapatkan pasokan oksigen yang cuku. Selain itu, tanaman dan tumbuhan tersebut akan menjadikan lingkungan sekolah sejuk, teduh, rindang dan nyaman, sehingga kegiatan belajar mengajar di kelas menjadi kondusif.

\section{METODE PENELITIAN}

Penelitian menggunakan pendekatan kualitatif jenis studi kasus. Penelitian ini merupakan studi multi situs tentang evaluasi program manajemen pembelajaran pada sekolah adiwiyata Kalimantan Timur, Studi Multisitus di Sekolah Menengah Umum Negeri 8 Samarinda dan Sekolah Menengah Umum Negeri 1 Tenggarong Kalimantan Timur.

Teknik pengumpulan data yang digunakan antara lain: a) observasi, penelitian ini melihat Evaluasi Program Manajemen Pembelajaran Pada Sekolah Adiwiyata Kalimantan Timur, b) wawancara mendalam dengan tujuan 
Al-Tanzim : Jurnal Manajemen Pendidikan Islam E-ISSN: 2549-5720 P-ISSN: 2549-3663

Vol. 03 No. 02 (2019) : 85-96

https:// ejournal.unuja.ac.id/index.php/al-tanzim

untuk menggali keterangan-keterangan dan informasi penting dari informan yang berkaitan tema penelitian, c) dokumentasi, digunakan untuk mencari data melalui beberapa arsip dan dokumentasi, surat kabar, majalah, jurnal, buku, dan benda-benda tertulis lainnya yang relevan

Setelah data terkumpul, selanjutnya dilakukan analis dengan melihat secara mendalam tentang Evaluasi Program Manajemen Pembelajaran Pada Sekolah Adiwiyata Kalimantan Timur, dengan menggunakan teknik analisis data kualitatif model Miles dan Huberman, yaitu reduksi data, data display, penarikan kesimpulan.

\section{HASIL PENELITIAN DAN PEMBAHASAN}

\section{Evaluasi Program Manajemen Pembelajaran Pada Sekolah Adiwiyata Kalimantan Timur}

Hasil penelitian pada sekolah yang menggunakan pola manajemen pembelajaran teritegrasi dengan prinsip pengelolaan sekolah adiwiyata, hasil evaluasinya memperoleh 7,75 dengan katagori "Baik". Walaupun pada indikator evaluasi penggunaan bahan/media pembelajaran masih memperoleh hasil evaluasi 6,15 dengan katagori cukup. Pada pengelolaan pengembangan bahan ajar yang mengintegrasikan prinsip pengelolaan lingkungan hidup atau adiwiya memperoleh skor 7,43 dengan katagori "Baik". Sedangkan secara keseluruhan, manajemen pembelajaran Pendidikan Agama Islam yang terintegrasi dengan pendidikan lingkungan hidup diperoleh skor 7,59 dengan katagori "Baik". Hasil evaluasi dengan katagori baik disebabkan oleh dukungan kebijakan kepala sekolah, manajemen pembelajaran Pendidikan Agama Islam yang baik.

Hasil evaluasi program manajemen pembelajaran melalui pendidikan lingkungan hidup dengan pola monolitik dan kegiatan ekstra kurikuler pendidikan lingkungan memperoleh skor 7,53 dari semua kriteria evaluasi yang sudah ditetapkan. Walaupun masih terdapat kesenjangan dalam kegiatan tersebut sebesar 2,47, namun pada hakikatnya pelaksanaan program adiwiyata di sekolah sudah mampu menumbukan sikap dan berbudaya lingkungan dan penanamkan nilai-nilai karakter dalam mencpai visi dan misi sekolah.

Program Adiwiyata akan menciptakan warga sekolah, khususnya peserta didik yang peduli dan berbudaya lingkungan, sekaligus mendukung dan mewujudkan sumberdaya manusia yang memiliki karakter bangsa terhadap perkembangan ekonomi, sosial, dan lingkungannya dalam mencapai pembangunan berkelanjutan di daerah. Dalam pelaksanaan program adiwiyata diletakkan pada dua prinsip dasar berikut ini; 1). Partisipatif: komunitas sekolah terlibat dalam manajemen sekolah yang meliputi keseluruhan proses perencanaan, pelaksanaan dan evaluasi sesuai tanggungjawab dan peran, dan 2). Berkelanjutan: Seluruh kegiatan harus dilakukan secara terencana dan terus menerus secara komprehensif. Dua prinsip adiwiyata merupakan sebuah upaya pencapaian visi dan misi sekolah. 
Sedangkan hambatan dalam keberlangsungan sekolah adiwiyata secara internal meliputi: a) menanamkan kedisiplinan dan ketertiban serta kesadaran mengenai lingkungan pada anak sekolah dasar masih mengalami kesulitan, b) monitoring keterlaksanaan program kurang maksimal dikarenakan bersamaan dengan program lain yang harus berjalan. Sedangkan kendala eksternal meliputi: a) lingkungan sekolah sebagai tempat bermain masyarakat saat kegiatan belajar mengajar selesai, terkadang fasilitas sekolah pendukung adiwiyata ada yang rusak, b) masih kurangnya kesadaran masyarakat di sekitar sekolah pada kepedulian lingkungan.

Dengan demikian manajemen pembelajaran Pendidikan Agama Islam yang mengintergrasi, monolitik dan dalam bentuk kegiatan esktrakurikuler dengan sekolah adiwiyata adalah suatu usaha untuk mencapai tujuan pembelajaran melalui proses perencanaan, pengorganisasian, pelaksanaan dan kontrol yang dilakukan pendidik dalam rangka mempersiapkan peserta didik untuk meyakini, memahami, dan mengamalkan ajaran agama Islam yang berbudaya lingkungan dengan hasil "Baik"

\section{KESIMPULAN}

Program adiwiyata ini diharapkan dapat merubah sikap dan perilaku siswa dan masyarakat pada umumnya untuk dapat menghargai lingkungannya. Keberadaan sekolah yang peduli dan berwawasan lingkungan akan dapat membangun pondasi pada diri siswa-siswi sebagai dasar dalam pembentukan etika lingkungan. Menanamkan pendidikan lingkungan hidup sejak dini di lingkungan sekolah akan menjadi bekal yang kuat bagi siswa dalam mewujudkan kesadaran dan kedisiplinan siswa, membuahkan budaya bersih dan sehat, serta munculnya perilaku-perilaku dan upaya-upaya pelestarian lingkungan, penghijauan serta perilaku hemat.

Pendidikan lingkungan hidup di lingkungan sekolah merupakan modal dasar bagi pembentukan etika lingkungan pada lintas generasi. Sekolah peduli dan berbudaya lingkungan merupakan pintu gerbang bagi siswa dalam membentuk perilaku yang beretika terhadap lingkungan. Penanaman etika lingkungan di lingkungan sekolah secara berkelanjutan diharapkan akan dapat tertanam kuat pada hati para siswa sehingga akan berbuah perilaku-perilaku yang mencintai alam berserta isinya. 
Al-Tanzim : Jurnal Manajemen Pendidikan Islam E-ISSN: 2549-5720 P-ISSN: 2549-3663

Vol. 03 No. 02 (2019) : 85-96 bttps:// ejournal.unija.ac.id/ index.php/al-tanzim

\section{DAFTAR PUSTAKA}

Adelia, V. (2010). Cara Mengajar Anak di Luar Kelas. Yogyakarta: Diva Press.

Amin, N., Siswanto, F., \& Hakim, L. (2018). Membangun Budaya Mutu yang Unggul Dalam Organisasi lembaga Pendidikan Islam. Al-Tanzim; Jurnal Manajemen Pendidikan Islam, 2(1), 80-93.

Anggreni, N. M. (2016). Konstruksi Budaya Mutu Relevansinya Dengan Manajemen Mutu Guru Dalam Pembelajaran Pendidikan Agama Hindu. Jurnal Manajemen Mutu, 2(2), 84-92.

Daryanto. (2013). Inovasi Pembelajaran Efektif. Bandung: Yrama Widya.

Dwi Rahmah, Y., \& Sjamsuddin Indradi, S. (2014). IMPLEMENTASI PROGRAM SEKOLAH ADIWIYATA (Studi pada SDN Manukan Kulon III/540 Kota Surabaya). Jap), 2(4), 753-757.

Fathorrazi, A. (2017). Kepemimpinan Kepala Sekolah Dalam Implementasi Dan Pengembangan Kurikulum 2013. Al-Tanzim : Jurnal Manajemen Pendidikan Islam, 1(1), 56-63.

Hakim, L. (2017). Penataan Pendidikan Islam Bermutu. Jurnal Pendidikan Agama Islam-Ta'lim, 15(1), 17-27.

Hallfreosdóttir, S. (2011). Eco Schools - Are They Really Better? Lund University.

Hamalik, O. (2002). Perencanaan Pengajaran Berdasarkan Pendekatan Sistem. Jakarta: Bumi Aksara.

Hamzah, N. M. (2012). Belajar dengan Pendekatan PAIKEM. Jakarta: Bumi Aksara.

Iswari, R. D., \& Utomo, S. W. (2017). Evaluasi Penerapan Program Adiwiyata Untuk Membentuk Perilaku Peduli Lingkungan di Kalangan Siswa (Kasus: SMA Negeri 9 Tangerang Selatan dan MA Negeri 1 Serpong). Jurnal Ilmu Lingkungan, 15(1), 35-41. https:/ / doi.org/10.14710/jil.15.1.3541

Maryani, I. (2014). Evaluasi Pelaksanaan Program Sekolah Adiwiyata Ditinjau dari Aspek Kegiatan Partisipatif di SDN Ungaran I Yogyakarta. Jurnal Pemikiran Dan Pengembangan SD, 1(3), 225-229.

Muhaimin. (2003). Wacana Pengembangan Pendidikan Islam. Yogyakarta: Pustaka Pelajar.

Pane, A., \& Darwis Dasopang, M. (2017). Belajar Dan Pembelajaran. FITRAH:Jurnal Kajian Ilmu-Ilmu Keislaman, 3(2), 333-352. https://doi.org/10.24952/fitrah.v3i2.945 
Pradini, I. K., Sudjanto, B., \& Nurjannah, N. (2018). Implementasi Program Sekolah Adiwiyata Dalam Peningkatan Mutu Pendidikan Di Sdn Tanah Tinggi 3 Kota Tangerang. Jurnal Green Growth Dan Manajemen Lingkungan, 7(2), 122-132. https:/ / doi.org/10.21009/jgg.072.03

Samrin. (2015). Pendidikan Agama Islam dalam Sistem Pendidikan Nasional Indonesia. Jurnal Al-Ta'dib, 8(1), 101-116.

Sungkowo. (2005). Konsep Pendidikan Lingkungan Hidup Pada Jalur Pendidikan asar Ddan Menengah. Jakarta: Dikdasmen.

Suyatno. (2015). Sekolah Dasar Islam Terpadu Dalam Konsepsi Kelas Menengah Muslim Indonesia. Analisa Journal of Social Science and Religion.

Syafrudin, A. (2016). Evaluasi Program Adiwiyata SDN 06 Kelapa Dua Jakarta Barat. Jurnal Penelitian Pendidikan Dan Penilaian Pendidikan, 1(2), 257-273. https://doi.org/10.22236/JPPP

Syamsuddin. (2017). Penerapan Fungsi-Fungsi Manajemen Dalam Meningkatkan Mutu Pendidikan. Jurnal Idaarah, I(1), 60-73. Retrieved from http://journal.uinalauddin.ac.id/index.php/idaarah/article/download/4084/3773

Tompodung, T. C. G., Rushayati, S. B., \& Aidi, M. N. (2018). Efektivitas Program Adiwiyata Terhadap Perilaku Ramah Lingkungan Warga Sekolah Di Kota Depok. Jurnal Pengelolaan Sumberdaya Alam Dan Lingkungan (Journal of Natural Resources and Environmental Management), 8(2), 170-177. https:/ / doi.org/10.29244/jpsl.8.2.170-177

Wibowo, A. (2018). Study Komparasi Penyelenggaraan Pendidikan SMK (Studi Kasus SMK Di Pondok Pesantren Lirboyo Al-Mahrusiyah Dan Di SMK PGRI 2 Kediri). At-Tarbiyat, 1(1), 1-22.

Wiyani, N. A. (2013). Manajemen Kelas. Yogyakarta: Ar-Ruzz Media. 